\title{
Pendidikan Ilmu Astronomi \\ Dari Historis Sampai Heliosentris
}

\author{
Nabil \\ STIT Al Marhalah Al Ulya Bekasi \\ Email: anisbata124@gmail.com
}

\begin{abstract}
Abstrak
Science in human life is very important to illuminate every walk of life, both physical (material) and metaphysical (immaterial). The universe was born millions and even billions of years ago, so many astronomical physicists calculate the origin of the universe, so the creation of the theory of bigbang, black holes, dark energy, dark matter, newton gravity, etc. Astronomy is important in teaching to know the phenomena of the universe (general), and to know times of worship (specifically). Before entering the science, it is better to know the history of astronomy, both the history of theory, and the figures then the hierarchy between geocentric and heliocentric in several views, both from the view of a character, as well as the view of the scriptures. Indeed, when humans think about the universe, in this case about the center of the universe there will be a hierarchy with the scriptures. This is a matter between different reason and revelation. Therefore, in this paper I touch on the issue of Heliocentric and Geocentric. And do not forget the astronomical figures from the West and East.
\end{abstract}


Nabil

\section{Pengertian Ilmu Falak}

Ilmu Falak dalam Bahasa Arab “أفلأك , فُلْك , jamak dari , menurut Bahasa orbit atau lintasan benda-benda langit. Dalam al-Quran, kata falak disebut sebanyak 2 kali dengan redaksi kalimat yang hampir sama. Pertama di dalam surat al-Anbiyā (21): 33,

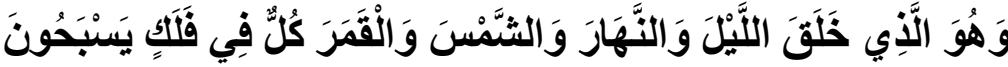

Dan Dialah yang telah menciptakan malam dan siang, matahari dan bulan. Masing-masing dari keduanya itu beredar di dalam garis edarnya. (Q.S. al-Abiyā (21): 33)

Kedua di dalam surat Yāsin (36): 40,

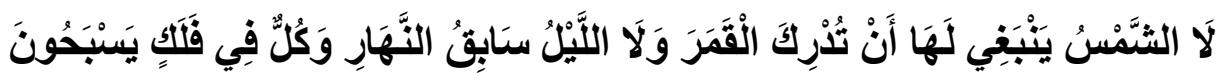

Tidaklah mungkin bagi matahari mendapatkan bulan dan malampun tidak dapat mendahului siang. Dan masing-masing beredar pada garis edarnya. (Q.S. Yāsin (36): 40)

Dari kedua ayat ini, secara gamblang hanya disinggung Matahari dan bulan. Dari sinilah istilah penggunaan nama ilmu Falak. Ilmu Falak menurut Istilah adalah ilmu pengetahuan yang mempelajari lintasan benda-benda langit matahari, bulan, dan bumi- pada orbitnya masing-masing dengan tujuan untuk diketahui posisi benda langit antara satu dengan lainnya agar dapat diketahui waktu-waktu di permukaan bumi (Khazin, 22004:3). Menurut Syeikh Zubair Umar Zailani, ilmu Falak adalah:

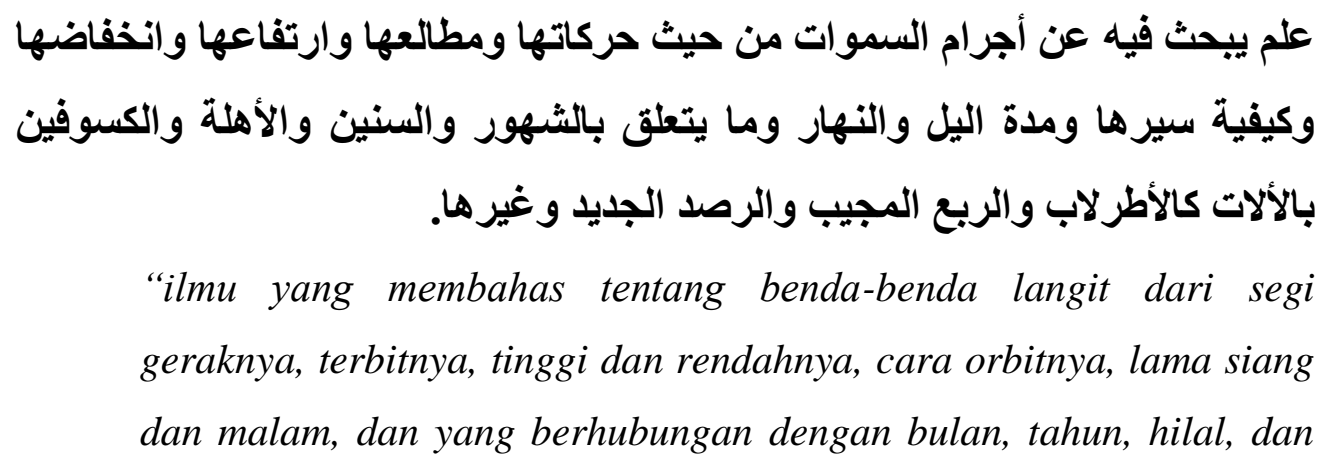


gerhana matahari maupun bulan dengan alat seperti globe, rubu', kalkulator, dll."

Ilmu Falak tidak berbeda jauh dengan ilmu Astronomi, karena kedua ilmu tersebut mengkaji benda-benda langit. Namun, karena ilmu falak ruang lingkupnya lebih spesifik pada kajian Islam, maka sering disebut ilmuwan muslim dengan Astronomi Islam. Bisa dikatakan, ilmu Falak merupakan cabang Astronomi yang fokus mempelajari matahari dan bulan. Sedangkan Astronomi secara umum meliputi seluruh aspek kajian terhadap benda-benda langit dan hal-hal terkait yang melahirkan banyak cabang keilmuan, misal Astrofisika ${ }^{1}$, Astrometri ${ }^{2}$, Astromekanik $^{3}$, kosmografi $^{4}$, dan kosmologi ${ }^{5}$.

Ilmu Falak disebut juga ilmu hisāb (الحساب), karena ilmu ini menggunakan perhitungan. Ilmu Falak disebut juga ilmu rashd (الرصد), Karena ilmu ini memerlukan pengamatan. Ilmu Falak disebut juga ilmu $m \bar{\imath} q \bar{a} t$ (الميقات), karena ilmu ini mempelajari tentang batas-batas waktu. Ilmu falak disebut juga ilmu haiah (الهيئة), karena ilmu ini mempelajari keadaan benda-benda langit.

\footnotetext{
1. Cabang ilmu Astronomi yang berhubungan dengan fisika jagat raya, termasuk sifat fisik (luminositas, kepadatan, suhu, dan komposisi kimia) dari objek Astronomi seperti planet, bintang, galaksi, dan medium antarbintang dan juga interaksinya.

${ }^{2}$. Cabang ilmu Astronomi yang memusatkan perhatian pada posisi bintang dan benda langit lainnya, jarak dan pergerakannya. Sebagian astrometri melibatkan pembuatan tangga jarak kosmik. Astrometri adalah salah satu sub bidang ilmu yang paling tua, kembali ke zaman Hipparchus, yang menyusun katalog bintang yang pertama. Hipparchus juga menciptakan skala kecerahan yang masih dipergunakan sampai sekarang.

${ }^{3}$. Cabang ilmu Astronomi yang mempelajari gerak dan daya Tarik benda-benda langit(gaya gravitasi) dengan cara hukum dan teori mekanik.

4. Secara harfiah berarti pengukuran langit, yaitu ilmu yang mengkaji penggambaran alam semesta, baik langit maupun bumi (benda-benda langit lainnya). Kajian ini menghasilkan berbagai peta langit maupun bumi.

5. Kosmologi Dalam Bahasa Yunani ada dua frasa, "kósmos" yang berarti dunia dan logos artinya ilmu. Jadi kosmologi adalah ilmu yang mempelajari tentang struktur dan sejarah alam semesta berskala besar. Secara khusus, ilmu ini berhubungan dengan asal mula dan evolusi dari suatu subjek.
} 
Nabil

\section{Historisitas Ilmu Falak}

Keberadaan ilmu Falak tidak terlepas dari goresan tinta sejarah Astronomi. Pada masa awal perjalanan ilmu pengetahuan tentang perbintangan, manusia meyakini bahwa dirinya sebagai poros alam semesta. Setiap manusia melangkah dari satu tempat ke tempat yang lain, ia selalu ditemani bintang yang sedang mengikutinya. Dari sini, yang membuatnya "Aku adalah pusat alam semesta", yang dikenal dengan filsafat egosentris. "Ego" artinya saya dan "sentris" yang berarti pusat.

Seiring pemikiran manusia semakin maju, filsafat egosentris pun sedikit demi sedikit hilang, kemudian lahirlah filsafat geosentris. Filsafat ini dibawa pertama kali oleh Eudoxus (400-347 SM) ${ }^{6}$ dan dikembangkan oleh Aristoteles (384-322 SM), kemudian disempurnakan oleh Claudius Ptolemaeus (140 SM). Filsafat ini mengangap bahwa bumi sebagai pusat alam semesta. Teori ini untuk menjelaskan adanya gerak retrograde planet. Dalam buku Almagest kaya Ptolemeus bahwa semua benda langit bergerak melingkari sebuah titik dan membentuk suatu lintasan yang disebut epicycle. Epicycle ini bergerak dalam lingkaran lebih besar yang disebut dengan deferent. Walaupun Ptolemeus mengatakan bumi pusat alam semesta, tapi bumi bukanlah pusat deferent, melainkan terletak tidak jauh dari pusat deferent yang disebut equant.

Filsafat geosentris ini bertahan hampir selama 15 abad. Hal ini disebabkan oleh doktrin gereja ${ }^{7}$ yang begitu kuat kemudian digantikan

\footnotetext{
${ }^{6}$. Generasi awal astronom dari Yunani adalah: 1. Philolaos, lahir di Italia selatan pada abad ke-5 SM. Gagasannya adalah rotasi harian bintang-bintang dan gerakan matahari dengan berasumsi bahwa bumi menggambarkan sebuah lingkaran dalam siklus 24 jam mengelilingi sebuah api sentral, jantungnya alam semesta. Menurutnya ada 10 orbit atau bidang sekitar api pusat, yaitu Conterearth, Bumi, Bulan, Matahari, Venus, Merkurius, Mars, Jupiter Saturnus, dan bidang bintang-bintang tertentu (Dampier, 1989: 43). 2. Hicetas, dia lebih muda dari Philolaos, gagasannya adalah bumi melakukan rotasipada sumbunya dalam 24 jamini berarti selangkah lebih maju daripada Philolaos (Dampier, 1989: 110). 3. Syracuse. 4. Meton.

7. Paham geosentris ini menjadi kepercayaan terpisah bagi kaum gerejawan. Di Amerika Serikat tahun 1870-1920, anggota gereja Lutheran- Sinode Missouri menerbitkan artikel-
} $-96-$

Al Marhalah : Jurnal Pendidikan Islam. Volume. 2, No. 2 November 2018 
filsafat Heliosentris. Dalam buku De Revolutionibus Orbium Coelestium oleh Nicholas Copernicus (1473-1543 M) mencetuskan sekaligus mengkritisi teori yang lama dan menggantikan teori yang baru, yaitu matahari sebagai pusat alam semesta. Kata heliosentris diambil dari Bahasa Yunani, "helio" artinya matahari dan "sentris" artinya pusat. Meskipun Copernicus dianggap penemu heliosentris, sebenarnya konsep heliosentris lebih dahulu dikemukakan oleh Aristarchus dari Samos.

Dari pandangan Copernicus inilah merupakan kemenangan besar pertama sains atas agama sehingga tidak dapat dihindari bahwa sejumlah orang berpikir semua yang salah dengan dunia ini bermula dari sana.

\section{Tokoh-tokoh Ilmu Falak}

\section{Aristoteles (384-322 SM)}

Aristoteles berpendapat ada gerak alami, ia mengemukakan tentang sifat bawaan dari berbagai benda yang memberikan alasan untuk berbagai sifat tersebut daya instrik khusus dari benda itu sendiri. Jika benda bergerak sentripetal dan gerak jatuh bebas merupakan gerak alamiah dari sifat air dan tanah (bumi), sedangkan gerka sentrifugal dan loncatan ke atas merupakan sifat alamiah dari api dan udara, dan gerak sirkuler (melingkar) merupakan gerak alamiah dari sifat eter.

Ia beragumen tentang gerak paksa yang terjadi akibat pengaruh luar yang dikenakan kepada benda dan boleh kesembarang arah seperti dorongan atau tarikan bukan dari benda itu sendiri. Ia mempercayai konsep benda akan hanya bergerak apapun itu bentuknya, jika selalu diberi gaya, dan gerak akan

artikel yang menyerang teori astronomi kopernikan (Copernicus), dan geosentris banyak diajarkan di dalam sinode dalam periode tersebut. Kaum gerejawan meyakini tentang teori geosentris daripada heliosentris karena sesuai dengan Alkitab, yang secara harfiah mengindikasikan pergerakan Matahari dan Bulan yang dapat diamati mengelilingi Bumi, misalnya pada Yosua 10:12 di mana Matahari dan bulan dikatakan berhenti di langit, dan Mazmur 93:1 dimana dunia digambarkan tidak bergerak (Numbers, 1993: 237). 
berhenti jika gaya dihilangkan, dengan kata lain gerak pakas itu harus ada gaya yang terus menerus.

Aristoteles juga berpendapat percepatan benda berdasarkan berat benda, yakni makin berat benda, makin ceat benda akan jatuh ke tanah. Oleh karena itu, kecepatan benda menjadi proposional tergantung berat benda. Dari paham-paham tersebut Aristoteles menyimpulkan pusat alam semesta adala bumi, yang dikenal dengan Geosentris. Sedangkan bumi selalu dalam keadaan tenang tidak bergerak dan tidak berputar. Semua gerak benda-benda di angkasa mengitari bumi, lintasan atau orbit masing-masing benda angkasa berbentuk lingkaran dan geraknya pun menjadi gerak alami. Pergerakan benda-benda langit sangat sempurna terus menerus. Aristoteles belum mengenal adanya gaya gravitasi. Secara ilmiah, Aristoteles menjelaskan, langit ini hampa tidak ada penghalang bagi benda-benda untuk terus bergerak atau tidak ada gaya yang menimbulkan benda angkasa itu berhenti.

\section{Claudius Ptolemaeus (140 SM)}

Ptolemaeus seorang pengarang beberapa risalah ilmiah, tiga diantaranya memainkan peranan penting dalam keilmuwan islam dan eropa. Yang pertama, risalah astronomi yang dikenal dengan Almagest (Risalah Besar). Kedua, risalah Geographia, yang merupakan diskusi teliti mengenai pengetahuan geografi Helenistik. Ketiga, risalah astrologi yang dikenal sebagai Tetrabiblos (Empat Buku) dimana dia berusaha mengadaptasi astrologi horoskop ke filosofi alam Aristotelian. Ia juga melestarikan daftar raja-raja kuno yang disebut Kanon Ptolemaeus, yang penting bagi penelitian sejarah timur tengah.

Ptolemaeus sesuai dengan pendapat Aristoteles tentang kosmos, yaitu geosentris bumi menjadi pusat tata surya. Benda-benda langit jaraknya dari bumi berturut-turut semakin jauh. Lintasan benda-benda langit tersebut 
berupa lingkarn di dalam bola langit. Sementara langit merupakan tempat bintang-bintang sejati sehingga mereka berada pada dinding bola langit.

\section{Nicolas Copernicus (1473-1543 M)}

Nicolas Copernicus sebagai bapak astronomi modern, ia dikenal dengan teori heliosentris, dimana bumi dan planet-planet lain mengelilingi matahari. Ia terinspirasi pada kritik Domenico Maria de Novara terhadap teori Ptolemaeus, paham yang percaya bahwa bumi adalah pusat tata surya di University of Bologna, Italia. Dia mempercayai planet mempunyai kecepatan mengelilingi matahari (revolusi) berbeda. Tergantung dari jarak dan ukurannya. Selain itu, Copernicus menjelaskan kalau bintang tidak bergerak, jika mereka seolah bergerak, itu terjadi karena bumi berputar.

Pendapat Copernicus ini dituangkan dalam bukunya De Revolutonibus yang mendapat kecaman langsung dari gereja Katolik Roma maupun Lutheran. Gereja Katolik Roma menyerukan bahwa teori Copernicus itu sesat dan tidak mempunyai bukti apa yang menyebabkan bumi mengorbit matahari. Kecaman pun juga dating dari Martin Luther ketika buku De Revolutonibus terbit.

Walaupun demikian, banyak masyarakat terpengaruh oleh teori Copernicus. Selama 50 tahun setelah buku De Revolutonibus terbit, teori Copernicus tidak cukup popular hingga akhirnya seorang astronomi Italia bernama Galileo Galilei membuat teleskop besar pada tahun 1609. Galileo lalu melakukan pengamatan langit, dan hasilnya ia meyakini kebenaran dari teori Copernicus.

\section{Galileo Galilei (1564-1642 M)}

Pada tahun 1609, seorang astronomi Italia bernama Galileo berhasil merampungkan teleskop astronomi pertamanya, dan kemudian mengarahkan teleskop ke langit. Hari itu ia berhasil melihat dunia baru yang penuh misteri yakni Jupiter. Galileo melihat 4 titik yang redup di sekeliling Jupier. 
Mungkin yang dimaksud bulan atau satelit dari planet Jupiter yang bernama Lo, Europa, Ganymede, dan Callisto. Keempat satelititu dikenal dengan nama satelit Galilean. Tidak hanya itu, Galileo berhasil melihat permukaan Bulan dan menikmati seluruh fase planet Venus. Ia bisa melihat Venus sabit maupun purnama. Gerak satelit Galilean mengelilingi Jupiter serta fakta seluruh fase Venus bisa dilihat dari Bumi, membuktikan bahwa bumi yang berputar mengelilingimatahari. Dengan demikian, penemuan Galileo menjadi pendukung bagi teori Heliosentris milik Copernicus.

Pada tahun 1612, muncul penolakan terhadap teori Copernicus, teori yang didukung oleh Galileo di tahun 1614 dari Tommaso Caccini. Pada tahun 1616, cardinal Roberto Bellarmino melarang mengajarkan teori Copernicus dan di tahun 1632 gereja Katolik menjatuhkan hukuman tahanan rumah bagi Galileo.

\section{Johannes Kepler (1571-1630 M)}

Johannes Kepler adalah took kunci dalam revolusi ilmiah abad ke-17. Dia terkenal karena hukum gerakan planetnya dan menggambarkan astronomi barunya sebagai fisika langit, sebagai perjalanan kemetafisika Aristoteles, dan sebagai suplemen untuk Aristoteles's On The Heaven, mengubah tradisi kuno kosmologi fisik dengan memperlakukan astronomi sebagai bagian dari fisika matematika universal. Pada tahun 1609 Kepler menerbitkan buku New Astronomy sebagai buku astronomi modern. Maha karya ini memuat dua hukum Kepler. Hukum pertama bentuk lingkaran orbit planet, bunyi hukum ini sebagai berikut: lintasan setiap planet mengelilingi matahari merupakan sebuah elips dengan matahari terletak pada salah satu titik fokusnya. Hukum kedua menjelaskan tentang kecepatan orbit planet, bunyi hukum ini sebagai berikut: setiap planet bergerak sedemikian sehingga suatu garis khayal yang ditarik dari matahari ke planet tersebut mencakup daerah dengan luas yang sama dalam waktu yang sama. Hukum yang ketiga 
diterbitkan dalam buku Harmonies of The World yang menjelaskan tentang periode revolusi planet. Periode revolusi planet ini dikaitkan dengan jari-jari orbit rata-ratanya, hukum ini berbunyi: kuadrat periode planet mengitari matahari sebanding dengan pangkat tiga rata-rata planet dari matahari.

Hukum-hukum Kepler ini akhirnya diakui kira-kira 70 tahun kemudian Isaac Newton menggunakan karya Kepler sebagai dasar untuk hukumnya tentang gerakan dan gravitasi. Dewasa ini, Kepler diakui sebagai salah satu ilmuwan terbesar sepanjang masa.

\section{Tradisi Astronomi Islam}

Dalam bidang astronomi, ilmuwan muslim pada dasarnyabanyak terinspirasi dari tiga peradaban, yaitu Yunani, Persia (Sassanian), dan India. Peradaban Yunani paling tidak dapat dilihat dari pengaruh Ptolemy. Beberapa astronom muslim memberikan komentar dan menerjemahkan kara Ptolemy (Batlamiyūs), yaitu Almagest ${ }^{8}$. Namun, perkembangan bidang ini berikutnya dipengaruhi oleh peradaban Persia dan India.

Perkembangan astronomi Islam pada pertengahan akhir abad ke-8 di Baghdad, mendasarkan karya astronomi muslim atas table astronomi Persia dan India. Karya astronomi penting yang masih terdapat dari Persia zaman pra Islam ialah Zīj-I Shāhī atau Zỉj-I Shahri-yārī (tabel raja), dibuat sekitar tahun 555, semasa raja dinasti Sassania, Anushirawan yang adil, ${ }^{9}$ dan daftar itu sendiri pada garis besarnya dibuat berdasarkan teori dan praktek astronomi bangsa India. Karya ini bagi astronomi Sassania bagaikan

\footnotetext{
${ }^{8}$. Karya ini awalnya berarti system yang besar yang kemudian diterjemahkan dalam bahasa Arab oleh Khalid b. Barmak menjadi al-Majisti. terjemahan Latin mengikuti terjemahan Arab, Almageste (Juljul, t.t: 36-37)

${ }^{9}$ Dinasti Sassania mengalami masa keemasan pada masa Anushirwan (531-579). Ketika itu Jundishapur menjadi pusat intelektual terbesar di mana ide0ide dari Yunani, Yahudi, Kristen, Syiria, Hindu, dan Persia dapat diperbandingkan, dipertukarkan, dan akhirnya disinkretiskan. Terjemahan ke dalam bahas Persia dari karya Aristotees dan Plato dibuat atas perintah Anushirwan. Jundishapur juga menjadi pusat pendidikan kedokteran yang sangat dipengaruhi Yunani, tapi dengan penambahan unsur Hindu, Syria dan Persia.
} 
Siddhanta bagi bangsa India dan Almagest untuk bangsa Yunani. Ia memainkan peran yang sangat penting dalam pembentukan astronomi Islam seperti apa yang dilakukan oleh kedua sumber tersebut (Siddhanta dan Almagest). Teks ini diterjemahkan dalam Bahasa Arab oleh Abu al-Hasan alTamimi dengan komentar oleh Abu Ma'syar, astronomi paling terkenal. Zỉj-I Shāhì merupakan dasar aktivitas astronomi para astronom terkenal. Seperti Ibn al-Nawbakht dan Masya'allah yang berkembang selama pemerintah alMansyur, dan yang membantu membuat kalkulasi awal untuk pembangunan kota Baghdad. Beserta beberapa naskah astrologi, dimana dinasti Sassania menekankan tentang konjungsi Jupiter-Saturnus tersiar di kalangan muslim, Zīj-I Shāhī merupakan warisan astronomi paling penting di Persia, Sasania, dan basis paling awal bagi astronomi Islam.

Melalui Astronomi resmi pertama dari dinasti Abbasiya, Muhammad al-Fazari, yang meninggal dunia sekitar tahun 777, pengaruh India menjadi dominan. Pada tahun 771satu misi India dating ke Baghdad, untuk mengajar sains di India dan membantu menerjemahkan teks India ke dalam Bahasa Arab. Satu atau dua tahun kemudian $Z \bar{\jmath} j-I S h \bar{a} h \bar{l}$ terbit, berdasarkan kitan Siddhanta oleh Brahmagupta. ${ }^{10}$ Al-Faziri juga mengarang beberapa syair astronomi, dan menjadi orang pertama kali di kalangan Islam yang membuat astrolab, yang kemudian menjadi instrument khas dalam astronomi Islam.

Selain al-Fazari, tokoh yang berperan dalam memperkenalkan astronomi India ke dalam Islam yaitu Ya'qub ibn Tariq yang belajar pada seorang guru India dan menjadi ahli dalam disiplin ilmu tersebut. Terutama karena usaha kedua orang ini, lebih dari yang lainnya, maka astronomi dan matematika India memasuki arus sains Islam.

\footnotetext{
${ }^{10}$. Brahmagupta dilahirkan tahun 598 dan hidup di Ujjain. Sekitar tahun 628 dia mengarang Brahmasphuta Siddhanta, sebuah system revisi dari Brahma yang didasarkan pada Surya Siddhanta dan Aryabhata tapi mengandung pengembangan orisinil. .
} 
Selama gerakan massif yang terjadi semasa pemerintahan al-Ma'mun, untuk menerjemahkan karya asing ke dalam Bahasa Arab, teks dasar astronomi Yunani juga bisa ditemukan, dalam konteks tertentu menggantikan karya India dan Persia, yang memonopoli bidang itu hingga saat ini. Almagest diterjemahkan berulang kali, juga Tetrabiblos dan table-tabel astronomi Ptolemeus, yang dikenal dengan nama Canones Procheiroi.

Dengan terjemahan ini dan yang lainnya lagi dari bahas Yunani dan Syiria, latar belakang kebangkitan astronomi Islam telah dipersiapkan, dan dalam abad ke-9, beberapa tokoh terbesar dalam sains ini muncul ke atas pentas, salah satunya:

\section{Abu Raihan al-Biruni (973-1048 M)}

Abu Raihan al-Biruni dikenal dengan nama panggilan al-Biruni, yang berarti asing, karena ia bertempat tinggal di kawasan yang dihuni oleh orangorang asing, tepatnya di pinggir kota Khawarizmi, Turkmenistan. Ia seorang Astronom muslim yang meyakini bahwa bumi ini bulat, berputar pada porosnya sehari sekali dan beredar mengelilingi matahari setahun sekali. Hal ini bertentangan dengan pendapat umum pada saat itu, namun diyakini alBiruni paling dekat dengan data-data empiris. Ia berbeda pendapat dengan pandangan Ptolemaeus, inilah yang kemudian melahirkan dukungannya pada teori heliosentris dan meninggalkan geosentris. ia pun berargumen bahwa orbit planet-panet ini bukan lingkaran tapi elips.

Al-Biruni pernah memecahkan persamaan geodesi kompleks jari-jari bumi sekitar $6339,9 \mathrm{~km}$, hanya selisih $16,8 \mathrm{~km}$ dari nilai modern yaitu 6356,7 $\mathrm{km}$. ia juga sebagai penemu alat pencari kiblat dan mengukur saat-saat solat di semua tempat di dunia.

\section{Muhammad ibn Ibrahim al-Fazari (796 M)}

Ibrahim al-Fazari merupakan tokoh yang hebat dalam ilmu astronomi dan matematika yang paling awal di dalam dunia Islam. Ia pernah membntu 
menerjemahkan teks astronomi India oleh Brahma Gupta (abad 7 M), Brahma Sphuta Siddhanta ke dalam Bahasa Arab sebagai kitab al-zij 'Ala Sinni al-'Arab (table astronomi berdasarkan penanggalan bangsa Arab). Buku Zij al-Sindhind adalah karya yang terdiri dari 37 simbol pada kiraan kalender astronomi dan 116 tabel dengan kalender. Iapun telah menemukan yang sangat menakjubkan yaitu Astrolabe, sebuah alat pengukuran secara spesifik dengan menggunakan system peralatan tertentu dalam menyelesaikan problem yang berhubungan dengan waktu dan posisi matahari, bulan, dan bintang.

Atrolabe sesungguhnya bagian dari astronomi, bidang kajiannya hampir sama hanya saja astrolabe lebih spesifik dan dapat dikatakan bagian dari astronomi dalam arti umum. Astrolabe lebih operasional dan lebih praktis, astrolabe ini kemudian dikembangkan dalam program ilmu computer yang sekarang ini semakin canggih seperti astrolabe planispheris. Sebuah sumber menyebutkan jumlah astrolabe pada abad 12 berjumlah 800 buah yang bertebaran di sejumlah negeri muslim. Konon salah satu diantaranya dimiliki pengembara sekaligus ilmuwan Bugis Makassar bernama Karaeng Pattingalloang. Sayangnya alat ini hancur dalam perang saudara antara Kerajaan Bugis dan Kerajaan Makassar.

\section{Abu Ja'far Muhammad ibn Musa Al-Khoarizmi (780-847 M)}

Al-Khoarizmi adalah seorang ahli matematika, astrologi, dan geografi yang berasal dari Persia. Ia lahir tahun 780 di Khoarizmn (sekarang Khiva, Uzbekistan). Buku pertamanya yaitu Al Jabar yang membahas tentang solusi sistematik dari linear dan notasi kuadrat sehingga ia disebut sebagai Bapak Aljabar. Al-Jabar merupakan cabang matematika yang mempelajari penyedehanaan dan pemecahan masalah menggunakan symbol sebagai ganti konstanta dan variabel. Selain itu, al-Khoarizmi adalah orang pertama kali menemukan angka nol. Angka nol adalah suatu angka dan digit angka yang 
digunakan untuk mewakili angka dalam angka.angka no; memainkan peran penting dalam matematika, yakni sebagai identitas tambahan bagi bilangan bulat, bilangan real, dan struktur al-jabar lain. Sebagai angka, nol digunakan untuk tempat dalam system tempat.

Angka nol dalam Bahasa arab, Shifr diserap ke dalam Bahasa Perancis menjadi Chiffre, dalam Bahasa Jerman menjadi Ziffer, dan dalam Bahasa Inggris menjadi Cipher.

Dalam bidang astronomi, Al-Khoarizmi membuat tabel perhitungan astronomi yang dapat digunakan untuk mengukur jarak dan kedalaman bumi yang dimuat dalam bukunya yang berjudul as-Sanad Hind. Dan juga ia menulis buku-buku astronomi lain, seperti bukunya yang berjudul al-Amal bi al-Istharlah dan Jadwal al-Nujum wa Haraktuha.

\section{Abu Ma'syar (w.886 M)}

Abulmazar, nama panggilan Abu Ma'syar. Ia dilahirkan di Balkh (Persia) pada 10 Agustus 787 M. Abu Ma'syar merupakan seorang ilmuwan serba bisa, selain dikenal sebagai ahli astrologi, Abu Ma'syar juga menguasai matematika, astronomi, dan filsafat islam. Ia merupakan salah satu murid dari al-Kindi, ilmuwan muslim di abad ke-8 M.

Dalam buku Introductorium in Astronomiam and De Magnis Coniuctionibus, Abu Ma'syar mengatakan bahwa dunia diciptakan ketika tujuh planet bergabung dengan Aries, dan ramalan itu bisa berakhir ketika fenomena yang sama terjadi pada Pisces.

\section{Abu Bakar al-Hasan ibn al-Hasib}

Abu Bakar al-Hasn ibn al-Hasib dikenal di Eropa dengan sebutan Albubacer dengan bukunya al-Mawalid. Ia berasal dari Persia yang hidup di penghujung abad ke-9. 


\section{Al-Nayrizī}

Al-Nayrizī yang bernama lengkap Abu al-'Abbas al-Fadl ibn Hatim Al-Nayrizī berasal dari nayriz dekat Shiraz. Dia hidup pada masa pemerintahan al-Mu'tadid (892-902) yang dikenal sudah memasuki secara politik. Namun, di bawah pemerintahan Al-Nayrizī mengumpulkan table astronomi tentang fenomena atmosfer. Dia banyak membuat komentar tentang karya Euclid (Element) dan Ptolemy (Almagest). Dia menulis naskah terlengkap yang dikarang dalam Bahasa Arab mengenai astrolob bola.

\section{Thabit ibn Qurrah}

Thabit ibn Qurrah sebagai astronom sekaligus dokter dan matematikawan. Nama aslinya Abu al-Hasan Thabit ibn Qurrah ibn Marwan al-Harrani yang berasal dari Harran, lahir tahun 826-827. Dia hidup di Baghdad dan meninggal tahun 901. Dia termasuk penerjemah yang hebat yang menerjemahkan dari Bahasa Yunani dan Syiria ke Bahasa Arab. Diantara hasil terjemahannya adalah karya Appolonios, Archimedes, Euclid, Theodosios, Ptolemy, Galen, dan Eutocios. Ia terkenal karena mempertahankan teori gerak getaran dari equinox. Untuk menjelaskna getaran ini, ia menambahkan bola ke Sembilan kepada delapan bola astronomi Ptolemy, satu hal penting yang diterima oleh kebanyakan astronom muslim yang kemudian.

\section{Al-Battani}

Al-Battani dikenal dengan nama Albategnius, nama lengkapnya Abu Abdallah Muhammad ibn Jabir ibn Sinan al-Battani, al-Harrani, al-Sabi dilahirkan sebelum tahun 858 di dekat Harran (Browne, 1902-24: 363). AlBattani dianggap sebagai astronomi muslim terbesar, segera mengikuti Thabit ibn Qurrah dan meneruskan garis studinya, meskipun menolak teori gerakan tersebut. Al-Battani membuat beberapa observasi yang paling akurat dalam sejarah astronomi Islam. Ia menemukan peningkatan opogium 
matahari semenjak zaman Ptolemy, yang menyebabkan penemuan gerak apsis matahari. Ia menetapkan presisnya sebesar 54.5" dalam satu tahun, dan inklinasi ekliptik sebesar $23^{\circ} 35^{\prime}$. Ia juga menemukan metode baru dan membuat studi terperinci mengenai gerhana matahari dan bulan, yang masih digunakan pada abad ke-18 oleh Dunthorn dalam menentukan perubahan gradual gerak bulan. Karya penting astronomi al-Battani, yang juga memuat seberkas table, dikenal di Barat sebagai De Scientia Stellarum (mengenai Sains Bintang). Ia adalah salah satu karya dasar astronomi hingga zaman Renaisans.

\section{Geosentris dalam Alkitab}

Dalam Alkitab menjelaskan bahwa geosentris menjadi teori yang mendasar bagi alam semesta. Hal ini terdapat pada ayat Yosua, 10:12 dan 10:13:

Lalu Yosua berbicara kepada Tuhan pada hari Tuhan menyerahkan orang itu kepada orang Israel; ia berkata di hadapan orang Israel: matahari, berhentilah di atas Gibeon dan engkau, bulan, di atas lembah Ayalon!. Maka berhentilah matahari dan bulan pun tidak bergerak, sampai bangsa itu membalaskan dendamnya kepada musuhnya. Bukankah hal itu telah tertulis dalam kitan orang jujur? Matahari tidak bergerak di tengah langit dan lambat-lambat terbenam kira-kira sehari penuh. (Yosua,10:12-13)

Ayat di atas memberikan kepada kita bahwa Alkitab menganut paham Geosentris, yakni bumi sebagai tata surya dan matahari mengelilingi Bumi. Bisa dilihat dari ayat di atas dimana dikatakan bahwa matahari berhenti dan tidak bergerak. Kitika waktu malam dan siang terjadi begitu lama karena adanya keberhentian rotasi.

Ayat-ayat lain yang mendukung bahwa Alkitab menganut teori geosentris diantaranya: 
Matahari, bulan berhenti di tempat kediamannya, karena cahaya anak-anak panahMu yang melayang laju, karena kilauan tombakMu yang berkilat (Habakuk,03:11)

Tetapi gema mereka terpancar ke seluruh dunia, dan perkataan merea sampai ke ujung bumi. Ia memasang kemah di langit untuk matahari (19:4). Yang keluar bagaikan pengantin laki-laki yang keluar dari kamarnya, girang bagaikan pahlawan yang hendak melakukan perjalanan (19:5). Dari ujung langit ia terbit, dan ia beredar samapi ke ujung yang lain; tidak ada yang terlindung dari panas sinarnya (19:6). (Mazmur, 19:4-6)

Pada kitab Mazmur semakin jelas bahwa matahari itu beredar mengelilimgi bumi. Matahari keluar dan beredar mengelilingi bumi. Dan pada ayat tersebut juga dikatakan bahwa tidak ada yang terlindungi dari panas sinarnya. Hal ini sekaligus membuktikan bahwa Alkitab menganut paham bahwa bumi itu datar, karena bumi yang bulat tidak mungkin bisa tersinar oleh matahari secara penuh, pasti ada bagian yang terlindungi dari sinar matahari.

\section{Hierarki Geosentris}

Tanpa disadari, teori heliosentris menjadi ancaman besar kepada kaum gerejawan, dengan Bahasa fenomologi akan memaksa orang mengakui kesalahan Alkitab. Sejumlah pemimpin Yudaisme Ortodok, terutama Lubavitcher Rebbe mempertahankan teori geosentris berdasarkan ayat-ayat Alkitab dan penafsiran Maimonides sehingga ia mengajarkan bumi dikitari matahari (Nussbaum, 2002: 38-43). Lubavitcher Rebbe juga menjelaskan bahwa geosentris dapat dipertahankan berdasarkan teori Relativitas, dimana dinyatakan bahwa "ketika dua benda di udara bergerak relative satu sama lain, ilmu alam mendeklarasikan dengan kepastian absolut bahwa dari segi sudut pandang ilmiah kedua kemungkinan itu valid, yaitu bumi mengitari matahari atau matahari mengitari bumi (Gotfryd, 2003: 76ff) 
Meskipun geosentrisme penting untuk perhitungan kalender Maimonides, mayoritas sarjana agamawi Yahudi yang menerima ke-ilahian Alkitab dan menerima aturan-aturannya mengikat secara hokum, tidak percaya bahwa Alkitab maupun Maimonides memerintahkan untuk percaya pada geosentrisme. Namun ada bukti bahwa kepercayaan geosentrisme meningkat di antara umat Yahudi Ortodoks.

Dalam sudut pandang dunia Islam modern, hanya sedikit individu yang mengajarkan suatu pandangan geosentris alam semesta. Salah satunya adalah Abd al-Aziz ibn Abd Allh ibn Baaz (1993-1999). Menurutnya bumi itu berputar dan matahari itu tetap sebagaimana di dalam al-Quran dan Sunnah serta kesepakatan para ulama dan realita yang ada. Sedangkan Syeikh Muhammad ibn Shalih al-Utsaimin mengatakan bahwa matahari mengelilingi bumi berdampak adanya siang dan malam, maka dari itu ia berpegang dengan zahir dari nash al-Kitab dan Sunnah.

Menurut Syeikh Albani, dalam ilmu geografi bumi memang bulat dan berputar, akan tetapi dalam ilmu agama, ia lebih cendrung memilih pendapat bahwa bumi dalam keadaan tetap dan datar dengan dalil yang tersirat, karena tidak ada dalil yang tegas bahwa bumi itu bulat.

Pergulatan begitu keras di awal masa sains, antara pandangan Ptolemaeus yang melahirkan geosentris dan Copernicus yang melahirkan heliosentris. Menurut Albert Einstein sebenarnya tidak berarti, kedua system koordinat dapat digunakan dengan justifikasi setara. Kedua kalimat: "matahari diam dan bumi bergerak", atau "bumi diam dan matahari bergerak", hanya bermakna konvensi yang berbeda dari dua system koordinat yang berbeda (Einstein, t.t: 212). Hal ini senada dengan apa yag dikatakan oleh Stephen Hawking dalam bukunya The Grand Design: maka apakah yang sesungguhnya, system ptolemaik atau kopernikan? Meskipun tidak jarang 
Nabil

orang mengatakan kopernikus membuktikan ptolemaeus salah, hal ini tidak benar (Hawking, t.t: 41)

\section{Daftar Pustaka}

Numbers, Ronald L, (1993), The Creationists: The Evolution of Scientific Creationism, (California: University of California Press)

Nussbaum, Alexander (2002), Creationism and Geocentrism Among Orthodox Jewish Scientists, (Reports of the National Center for Science Education, January-April 2002)

Gotfryd, Arnie, (2003), Mind over Matter: The Lubavitcher Rebbe on Science, Technology and Medicine. (Shamir)

Eisntein, Albert (t.t), The Evolution of Physics: From Early Concepts to Relativity and Quanta.,

Hawking, Stephen (t.t), The Grand Design.,

Dampier, Sir William Cecil, A History of Science and Its Relations with Philosophy and Religion, (New York: Cambridge University Press, 1989)

Juljul, Ibn, Tabaqāt al-Atibba' wa al-Hukama', ed. Fuad Sayyid, (Kairo: Matba'at al Ma'had al-'Ilm al-Faransi, tt)

Browne, E.G, A Literary of Persia, (Cambridge, UK: Cambridge University Press, 1902-24), Vol. I, 363 